\title{
Spatial-temporal variation and modeling of rainwater quality
}

\author{
Variação espaço-temporal e modelagem da qualidade da água pluvial \\ Variación espacio-temporal y modelización de la calidad del agua de lluvia
}

Received: 03/05/2021 | Reviewed: 03/13/2021 | Accept: 03/15/2021 | Published: 03/22/2021

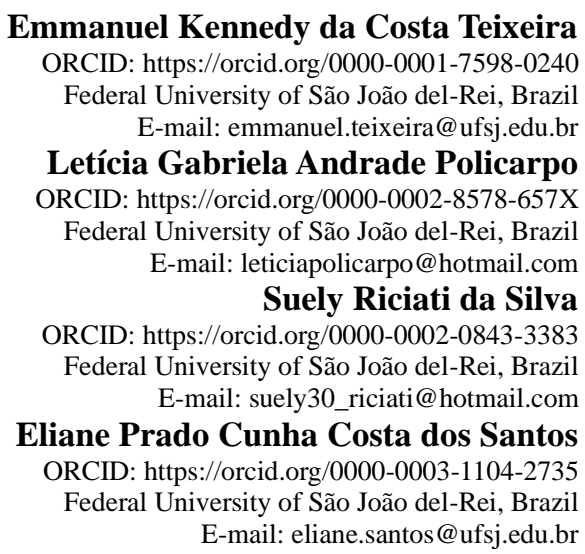

\begin{abstract}
Rainwater harvesting (RWH) is an alternative to the problem of water scarcity. However, its quality must be analyzed before its use, so that it does not represent any danger to the consumer. Thus, the objective of this paper was to analyze the spatial-temporal variation of water quality of rainwater in two cities and observe whether its parameters meet the norm related to the subject. In addition, the concentration of total suspended solids (TSS) that flow into the drainage system was also simulated. Rainwater samples were collected at several points in Congonhas and Ouro Branco - MG, over a period of two years. The results showed that there was spatial-temporal variation in water quality. There were points where the quality met the standard in some moments and did not meet in others, due to its temporal variation. It was also observed that the catchment surface influenced the quality of rainwater, so that the water that came into contact with the roof had its quality deteriorated, at first. However, throughout the rainy event, the quality improved, but at certain times, it was not enough to meet the standard. The rainwater quality simulation, carried out at SWMM, showed high concentrations of TSS, which were higher to that allowed for launching into receiving bodies.
\end{abstract}

Keywords: NBR 15527/2007; SWMM; Catchment surface; Water scarcity.

\section{Resumo}

A captação da água pluvial (CAP) é uma alternativa ao problema de escassez hídrica. Porém, sua a qualidade deve ser analisada antes do seu uso, para que não represente nenhum perigo ao consumidor. Assim, o objetivo deste trabalho foi analisar a variação espaço-temporal da qualidade da água pluvial em duas cidades e observar se os seus parâmetros atendem à norma referente ao assunto. Além disso, também foi simulada a concentração de sólidos suspensos totais (SST) que escoam no sistema de drenagem. Foram coletas amostras de águas pluviais em diversos pontos de Congonhas e Ouro Branco - MG, em um período de dois anos. Os resultados mostraram que ocorreu variação espaçotemporal da qualidade da água. Houve pontos em que a qualidade atendeu a norma em alguns momentos e não atendeu em outros, por conta da sua variação temporal. Também foi observado que a superfície de captação influenciou na qualidade da água pluvial, de forma que as águas que entraram em contato com o telhado tiveram sua qualidade piorada, em um primeiro momento. Porém, ao longo do evento chuvoso, a qualidade melhorou, mas, em determinados momentos, não foi o suficiente para atender à norma. A simulação da qualidade da água pluvial, realizada no SWMM, apresentou concentrações elevadas de SST, as quais foram superiores ao permitido para o lançamento em corpos receptores.

Palavras-chave: NBR 15527/2007; SWMM; Superfície de captação; Escassez hídrica.

\section{Resumen}

La captación de agua de lluvia es una alternativa al problema de la escasez de agua. Sin embargo, su calidad debe ser analizada antes de su uso, para que no represente ningún peligro para el consumidor. Así, el objetivo de este trabajo fue analizar la variación espacio-temporal en la calidad del agua de lluvia en dos ciudades y observar si sus parámetros cumplen con la norma relacionada con el tema. Además, también se simuló la concentración de sólidos 
suspendidos totales (SST) que fluyen hacia el sistema de drenaje. Se recolectaron muestras de agua de lluvia en varios puntos de Congonhas y Ouro Branco - MG, durante un período de dos años. Los resultados mostraron que hubo una variación espacio-temporal en la calidad del agua. Hubo puntos donde la calidad cumplió con el estándar en algunos momentos y no cumplió en otros, debido a su variación temporal. También se observó que la superficie de captación influyó en la calidad del agua de lluvia, por lo que el agua que entró en contacto con el techo empeoró su calidad, en un principio. Sin embargo, durante todo el evento lluvioso, la calidad mejoró, pero en ciertos momentos, no fue suficiente para cumplir con el estándar. La simulación de la calidad del agua de lluvia, realizada en SWMM, mostró altas concentraciones de SST, las cuales fueron superiores a las permitidas para su lanzamiento a los cuerpos receptores.

Palabras clave: NBR 15527/2007; SWMM; Superficie de captación; Escasez de agua.

\section{Introduction}

Nowadays, many regions face problems of scarcity and low quality of surface water. This fact is related to the intense urbanization, inadequate management of water resources, the increase in population, pollution and industrial and agricultural activities (Gaitan \& Teixeira, 2020). In order to paper around the problem, an alternative that has been increasingly practiced is rainwater harvesting (RWH) (Stahn \& Tomini, 2017). It consists of making, even in the place where the rain occurred, the concentration, which occurs from impermeable surfaces (Lopes et al., 2019), collection, storage and treatment of rainwater. Besides, this collection is simple to install and it has low frequency of maintenance and low energy costs (Santos \& Farias, 2017).

The collected water can be used in large buildings, for example, in airports (Moruzzi et al., 2016) and in single-family homes (Waso et al., 2020; Moruzzi \& Leão, 2019; Strauss, 2018; Bashara et al., 2018, Campisano et al., 2017; Chaib, 2015). Regarding the quantitative question, rainwater has a number of advantages in relation to some of its physicochemical parameters, when compared to that of surface watercourses (Sánchez et al, 2015), as less turbidity. The RWH can be also one of the Low Impact Development devices, as it provides a decrease in runoff that reaches the urban drainage system (Tarqui et al., 2019). Furthermore, it helps to preserve surface water bodies, since the pollutant load present in rainwater that would drain into the drainage system does not reach the receiving watercourse (Tsuji, 2018; Righetto et al., 2017).

Despite all the advantages of using rainwater, it must be analyzed before use, because there may be the presence of microbiological and chemical contaminants (Stewart et al., 2016), which could cause a potential health hazard for the consumer (Angala et al., 2019). Therefore, assessing the quality of urban rainwater remains a complex and challenging field, given the large number of factors involved (Behmel et al., 2016). According to Mimura et al. (2016), there are several studies on the quality of rainwater in the Northern Hemisphere, but there are few studies on this topic in Brazil.

Hagemann and Gastaldini (2016) assessed the quality of rainwater in the city of Santa Maria - RS, the variation of parameters during precipitation and the most appropriate uses for this water according to the current standards on the use of rainwater and reuse. Nakada and Moruzzi (2014) studied the quality and variability of rainwater drained and stored on the premises of the University Estadual Paulista. Fia et al. (2013) evaluated the dynamics of pollutants in rainwater and the supply of nutrients from rain in Lavras - MG. In these papers, the authors conclude that the quality of rainwater underwent temporal variation. In other words, at the same point analyzed, the quality of rainwater varied in different rainy events, mainly due to the deposition of solids during the drought. On the other hand, the authors did not verify the spatial variation in the quality of rainwater, since they made collections in only one place. However, this verification is necessary for planning the rainwater harvesting system. Sazakli et al. (2007) and Amodio et al. (2014), pointed out that emissions of traffic and industrial pollutants can promote spatial variation in the quality of rainwater in urban areas. Sánchez et al. (2015) showed that meteorological factors, characteristics of the particles, characteristics of the roof - such as its geometry, its material and its cleanliness - can make the quality of rainwater runoff vary spatially.

In Brazil, the collection, use of rainwater and sizing methods for the rainwater accumulation reservoir are regulated by 
means of the norm NBR 15527 (ABNT, 2007) (Brandão \& Marcon, 2018a; Brandão \& Marcon, 2018b). This norm also presents the quality parameters that rainwater must meet to be used (Marangoni et al., 2019). Therefore, it is important to verify that the quality of rainwater in the two cities surveyed is in accordance with NBR 15527 (ABNT, 2007). In addition, the quality variation was verified after passing through the catchment surface.

Thus, knowing the importance of RWH, the importance of analyzing water quality for its use, and the low production of papers addressing this issue for the study region, the study of rainwater quality was promoted in two neighboring cities. The main objective of this paper was to present that, even though the two cities are close and have common characteristics of land use and occupation, the quality of rainwater presents spatial-temporal variation. It stands out that other papers in the national literature have not studied the spatial variation in the quality of rainwater. It also aimed to present how the temporal variation in the quality of rainwater can affect the load of pollutants that reaches the watercourses, in order to assist in decision making in the management of rainwater. Thus, it is expected that this paper will contribute to future rainwater harvesting projects in the region

\section{Methodology}

\subsection{Study areas}

The present study was carried out in two cities in the state of Minas Gerais (Figure 1). The city of Congonhas-MG was chosen because it is located in the iron quadrilateral, a region characterized by mineralogical wealth, with a large presence of mining companies, that is to say, in a place prone to air pollution. Besides, pollution in the city is caused due to industrial activities and vehicle traffic both on urban roads and on the BR - 040 highway, which is located on the margins of the city and has a high flow of vehicles. The average total accumulated annually is $1386 \mathrm{~mm}$. The other place of study was the city of Ouro Branco-MG, which borders on Congonhas and is also in the iron quadrilateral. Furthermore, it currently has the steel industry as its main activity, which started the steel cycle. The city has an average annual accumulated total of $1463 \mathrm{~mm}$. Soil type of the two cities is sandy, formed from quartzite rocks; the vegetation is of rupestrian fields; and the climate is tropical in altitude.

Figure 1 - Study area location.

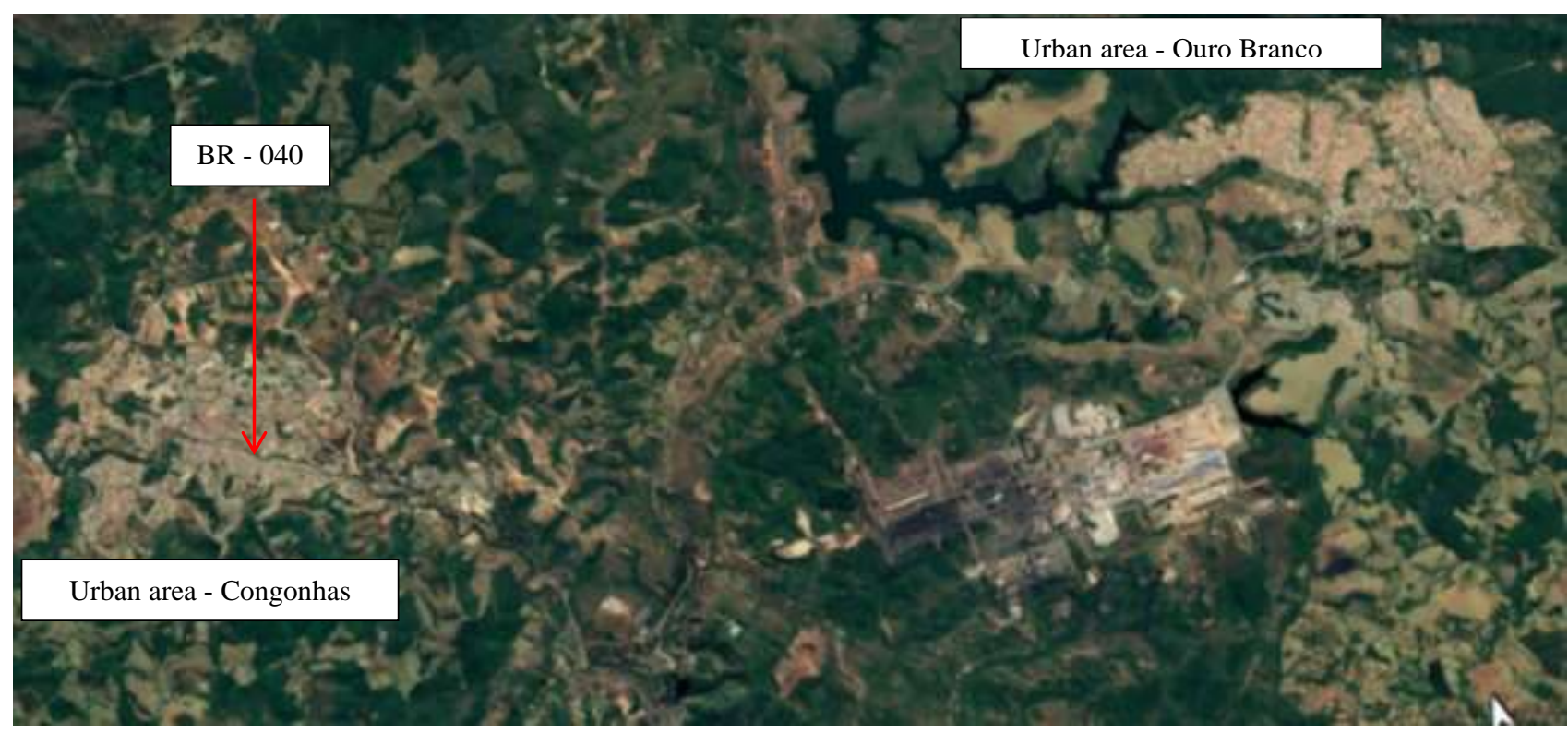

Source: Authors. 


\subsection{Spatial-temporal variation in rainwater quality and compliance with NBR 15527/07}

In order to verify the spatio-temporal variation in the quality of rainwater, samples were collected at various points in Congonhas and Ouro Branco, and the collections were made between August 2016 and March 2018, totaling 74 events analyzed. For Congonhas, the list of points and the reasons for their choices are shown in Table 1.

Table 1 - Sample collection points in the city of Congonhas.

\begin{tabular}{lr}
\hline Points & Justification \\
\hline CA 01 & $\begin{array}{r}\text { Residential neighborhood, with rainwater collected directly from the atmosphere } \\
\text { Same place as CA 01, but in this case the water was collected after draining on the } \\
\text { roof } 01\end{array}$ \\
CA 02 & $\begin{array}{r}\text { Located close to BR-040. A place with a large flow of cars, which are often dirty due } \\
\text { to the presence of residues from mining activities in the region }\end{array}$ \\
CA 03 & $\begin{array}{r}\text { Located close to the historic city center, the sculptures that make it up are susceptible } \\
\text { to corrosive processes, which can occur due to acid rain } \\
\text { CA } 04\end{array}$ \\
CA 05 & Locatral region of the city with high occupational density
\end{tabular}

Source: Authors.

Figure 2 shows the location of the points where samples were collected. Also presented are the distances, in a straight line, between the places where rainwater samples were collected ranged from $0.7 \mathrm{~km}$, between CA 03 and CA 04 , to $5.4 \mathrm{~km}$, between CA 02 and CA 05.

Figure 2 - Location of the points where samples were collected in Congonhas.

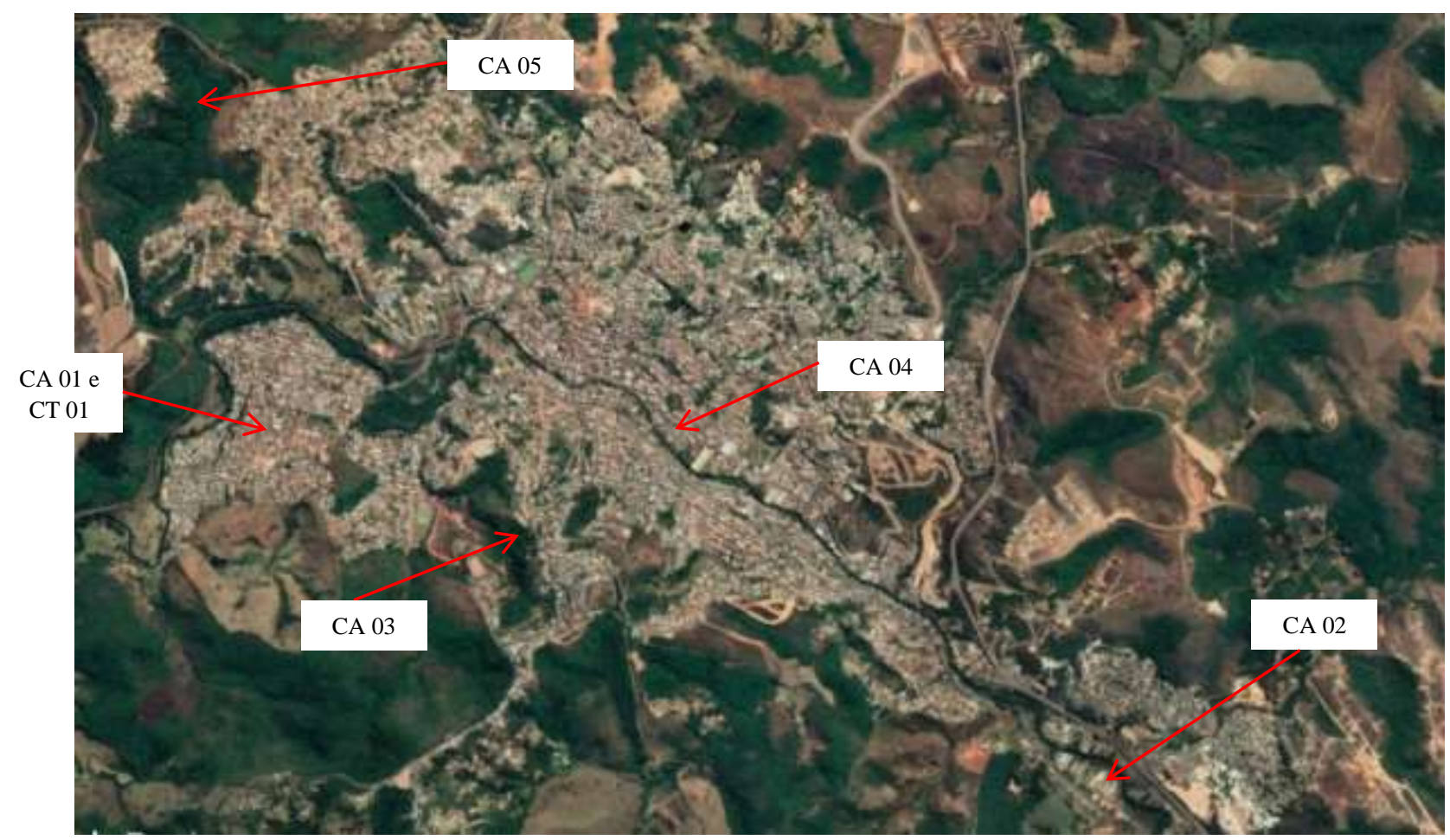

Source: Authors.

The list of points at which there were collected in Ouro Branco, as well as the justification for their choices are shown in Table 2. 
Table 2 - Sample collection points in the city of Ouro Branco.

\begin{tabular}{|c|c|}
\hline Points & Justification \\
\hline OA 01 & $\begin{array}{l}\text { Location close to MG-129 highway, which has a large flow of cars. Besides, the } \\
\text { point is close to the beginning of a closed forest with a high density of trees }\end{array}$ \\
\hline OA 02 & Central region of the city with high occupational density \\
\hline OA 03 & Near a pond, which has the presence of heavy metals \\
\hline OA 04 & Residential neighborhood, with rainwater collected directly from the atmosphere \\
\hline OA 05 & $\begin{array}{l}\text { Located close to a precast industry and on the side of a highway with a large volume } \\
\text { of light and heavy vehicles passing through }\end{array}$ \\
\hline OA 06 & Residential neighborhood, with rainwater collected directly from the atmosphere \\
\hline OT 06 & $\begin{array}{l}\text { Same place as OA 06, but in this case the water was collected after it drained from } \\
\text { the roof }\end{array}$ \\
\hline
\end{tabular}

Source: Authors.

Figure 3 shows the location of the points where samples were collected. Also presented are the distances between the collection sites in the city varied from $0.3 \mathrm{~km}$, between OA 03 and OA 04 , to $4.0 \mathrm{~km}$, between OA 01 and OA 05 . The point located in Ouro Branco closest to Congonhas is OA 06, which is $11.4 \mathrm{~km}$ away from point CA 02.

Figure 3 - Location of the points where samples were collected in Ouro Branco.

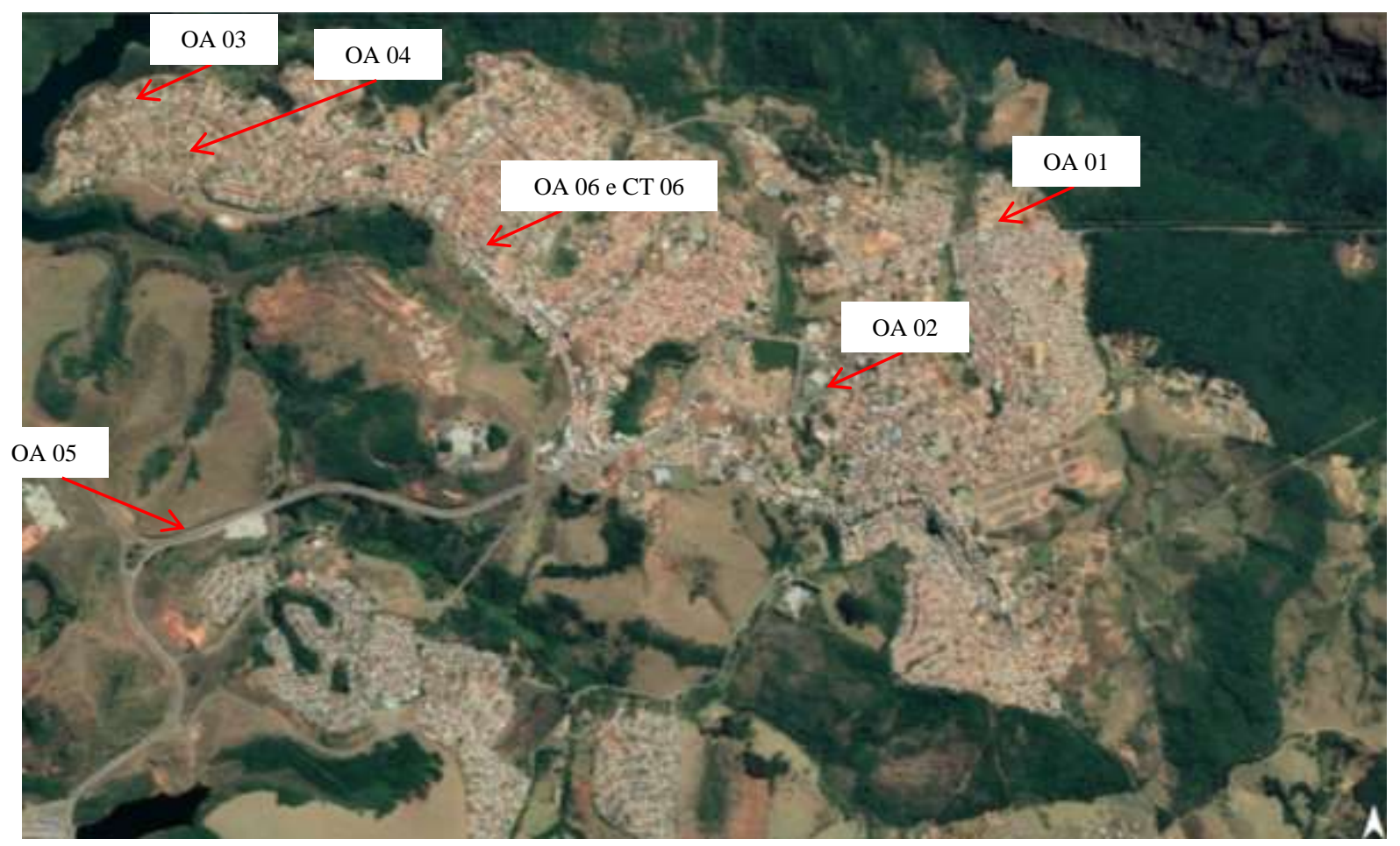

Source: Authors.

The collection of samples captured directly, in other words, those in which the water comes directly from the atmosphere and is deposited in the collector without previously passing through another means, it was based on the recommendations and guidelines of PROSAB (2009). Therefore, plastic material (PVC) collectors were used, protected by two layers of mesh, placed in order to prevent the entry of solids from vegetation, animals and soil particles that are loaded by the 
wind. Such collectors were $9.0 \mathrm{~cm}$ high and approximately $25.0 \mathrm{~cm}$ in diameter. The volume of the collectors was $4.0 \mathrm{~L}$, in order to guarantee that the water would not overflow during a rain. These collectors were cleaned before a rainy event to avoid possible changes in the characteristics of the collected water, as recommended by Hagemann and Gastaldini (2016). In order to check the possibility of rainwater contamination by the material that constitutes the plastic collector, a water quality test was carried out for all collectors. For this purpose, the parameters of conductivity, turbidity and $\mathrm{pH}$ of the rainwater were compared right after it was collected and after it remained $2.5 \mathrm{~h}$ inside the covered collector. Thus, it was concluded that the material was inert and could be used in the experiment, as also observed by Marangoni et al. (2019).

Following the PROSAB (2009) guidelines, the samples were taken from the collectors, shortly after the rains, homogenized and stored in polyethylene containers. It stands out that all collectors were tested for tightness before using them, to avoid problems during rainy events. Subsequently, the samples were taken to the laboratory to carry out the analysis procedures of the physical-chemical parameters, and they were performed within a maximum period of $24 \mathrm{~h}$ after the event. All analyzes were performed according to the Standard Methods for the Examination of Water and Wastewater (APHA; AWWA; WEF, 2012).

The NBR 15527 (ABNT, 2007) recommends the analysis of the following parameters for the characterization of rainwater: $\mathrm{pH}$, apparent color, turbidity, total coliforms and thermotolerant coliforms. However, due to the lack of some equipment, only the first three parameters were analyzed, which does not compromise the objective of this paper. In possession of the results, a comparison was made with the values recommended by the norm to conclude whether the quality of the rainwater in Congonhas and Ouro Branco accords with the norm. In order to assess the spatial variation in the quality of rainwater, the Student's " $\mathrm{t}$ " test was applied for two averages, at a significance level of $5 \%$, to verify if there was a significant difference between the mean values of the parameters found in each collection point. In Congonhas, for the three parameters analyzed, the results of the five points were compared with each other to verify if there was a significant difference between their means. The same was done for the six points collected in Ouro Branco. In addition, the quality of rainwater between the two cities was also compared.

\subsection{Variation in the quality of rainwater after passing through the catchment surface}

Samples were collected indirectly, that is, collected after the water flowed through the roof and the gutter, in order to analyze the variation in the quality of rainwater after it passed through the catchment surface. Such samples were captured by a collector connected directly to the gutter. For the structuring and assembly of this collector, the recommended in IPT (2015) was taken as a reference. Pollutant concentrations tend to be higher at the beginning of the rainy event, when compared to the middle or end of the event. According to Righetto et al. (2017) this is due to the initial removal of the material accumulated in the period between rains, so that the peak of the polutogram must occur, in many cases, before the peak of the flows. Thus, according to the recommendation by NBR 15227 (ABNT, 2007), 2.0 L of rainwater was collected per square meter of roof, this sample being known as "first flush" or waste water. As an area of $4.0 \mathrm{~m}^{2}$ was defined on the roofs used, the volume predicted in the collectors used was $8.0 \mathrm{~L}$, with dimensions of approximately $1.0 \mathrm{~m}$ in height and $100.0 \mathrm{~mm}$ in diameter. The collector is composed of a vertical segment in which the first drained water accumulated, and at the bottom of the tube there was a tap to remove this accumulated water. In the upper part of the collection tube, immediately after completing the $8.0 \mathrm{~L}$ of washing water, a branch was installed, which acted as an overflow.

The quality of rainwater collected indirectly was compared with that of water collected directly from the atmosphere. For this, in Congonhas the points CA 01 and CT 01 were installed in the same place, with the first rainwater being collected directly, while in the second the water was collected after it drained through the roof. The means of CA 01 and CT 01 for the three parameters analyzed were compared using the Student's " $t$ " test for two means, at a significance level of 5\%. The same 
was done in Ouro Branco using the samples collected at points OA 06 (rainwater collected directly from the atmosphere) and OT 06 (same location as OA 06, but in this case the water was collected after it drained from the roof). At point OT 06 he made the collections in two different ways. In one, the waste water samples were collected, this point being called OT $061^{\circ}$. In the other, samples of excess rainwater drained through the roof were collected, in other words, samples were collected that exceeded $8.0 \mathrm{~L}$, and in this case, the point was called OT $062^{\circ}$.

\subsection{Modeling rainwater quality}

One of the benefits of RWH consists in the fact that, from it, a lower load of pollutants contained in the surface runoff is released into the receiving body. For this reason, it carried out a simulation of the quality of rainwater in the drainage, in order to present the concentration of total suspended solids (TSS) that would no longer be released in the course of the water, in case the rainwater is captured. The modeling was carried out based on the data collected at OT $061^{\circ}$, in which samples related to the first flush were collected. This point was selected because there is an accumulation of pollutants that will reach the drainage system, during a rainy event, and later, will be released into a receiving body. At this point, in addition to the parameters already mentioned, the TSS values of the samples collected were also obtained. The mean TSS concentration found was $179.5 \mathrm{mgL}^{-1}$, which results in an amount of $3.6 \mathrm{kgTSSha}^{-1}$.

The Storm Water Management Model (SWMM) software was used to model the quality of rainwater flowing into the drainage system, which was developed by the Environmental Protection Agency (EPA). Its use was because of its wide use in hydraulic modeling and water quality of urban drainage systems (Hur et al., 2018; Girão et al., 2017; Rosa et al., 2015). In SWMM, the exponential function was used to describe the accumulation of TSS during the dry period prior to a precipitation event. This function is commonly adopted, as done by Tsuji (2019), Chen (2018), Hur et al. (2018) and Girão et al. (2017). With regard to leaching, the method used was the average concentration of TSS during rainy events. This method is recommended for when there are no measurements of pollutant concentrations throughout the drainage system (Thériault \& Duchesne, 2012), as was the case in this paper.

\section{Results and Discussion}

\subsection{Spatial-temporal variation in rainwater quality and compliance with NBR 15527/07}

Based on 74 rainy events that occurred between August 2016 and March 2018, for which rainwater samples were collected at points stipulated in Congonhas and Ouro Branco, it is possible to observe the temporal variation in the quality of the rainwater as to the apparent color, turbidity and $\mathrm{pH}$. The results of this variation are shown in Figures 4 to 7 . Nakada and Moruzzi (2014) also observed temporal variation in the quality parameters analyzed in the rainwater samples collected at the University Estadual Paulista, located on the Rio Claro campus.

Figure 4 shows the temporal variation of the apparent color of rainwater samples collected directly from the atmosphere. Five locations in Congonhas (CA 01 to CA 05) and six in Ouro Branco (OA 01 to OA 06) were analyzed. NBR 15527 (ABNT, 2007) recommends that the apparent color value of rainwater be less than $15.0 \mathrm{uH}$ (horizontal dashed line in Figure 4) for non-potable uses established by the norm. According to Figure 4, it can be seen that in Ouro Branco five of the six analyzed sites presented $100 \%$ of the samples collected are in accordance with the standard. In Congonhas, the apparent color was superior to that recommended in most of the analyzed samples, and in all the points there were more than 50\% of the samples with apparent color value above $15.0 \mathrm{uH}$. Values higher than recommended were also observed in the studies by Nakada and Moruzzi (2014). The high apparent color values can indicate the presence of organic matter, which can generate by-products in the disinfection process. Therefore, for the use of rainwater collected at these points, it is recommended to use techniques that remove organic matter or alternative techniques to chlorination should be used. At each point, the apparent 
color variation in Ouro Branco was less than in Congonhas. Thus, it is observed that the variation in air quality in Congonhas suffers greater variation between two rains.

Figure 4 - Temporal variation of the apparent color of rainwater collected directly from the atmosphere in Congonhas (CA) and Ouro Branco (OA).

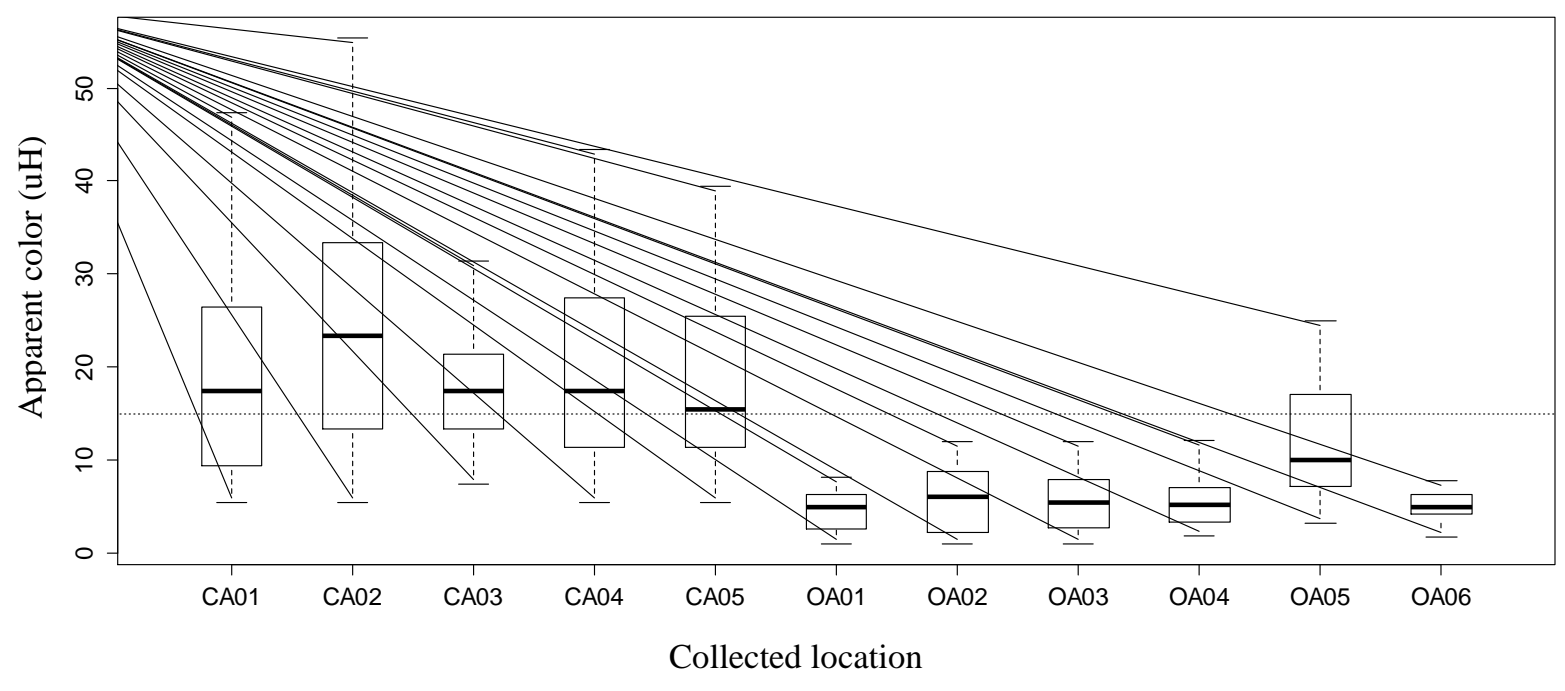

Source: Authors.

In Congonhas, the CA 02 point showed the highest apparent color values, with almost $75 \%$ of the samples collected having values greater than $15.0 \mathrm{uH}$. This point is located close to BR-040, being a place with a large flow of cars, which are often dirty due to the presence of residues from mining activities in the region. In Ouro Branco, point OA 05 was the one with the highest values, being that it was close to a precast factory. Both the high flow of cars on highways and the factory activities can influence the apparent color values, as suggested by Fia et al. (2013).

The temporal variation of rainwater turbidity collected directly from the atmosphere in Congonhas and Ouro Branco is shown in Figure 5. For more restrictive uses, NBR 15527 (ABNT, 2007) recommends values less than 2 uT and, for less restrictive, values less than $5 \mathrm{uT}$ (these limits are represented by the dashed horizontal lines in Figure 5). For the upper limit (5 uT), it is clear that in Congonhas most of the samples analyzed showed values lower than the recommended. All points had between 75 and $100 \%$ of the samples with turbidity following the recommended. On the other hand, in Ouro Branco all the analyzed sites presented at least 50\% of the samples with values higher than the norm, whereas in OA $05100 \%$ of the turbidity values were high. It turns out that the presence of particulate matter in the atmosphere affects the turbidity of rainwater. Thus, possibly Ouro Branco has a higher concentration of particulate matter in the atmosphere than Congonhas. 
Figure 5 - Temporal variation of rainwater turbidity collected directly from the atmosphere in Congonhas (CA) and Ouro Branco (OA).

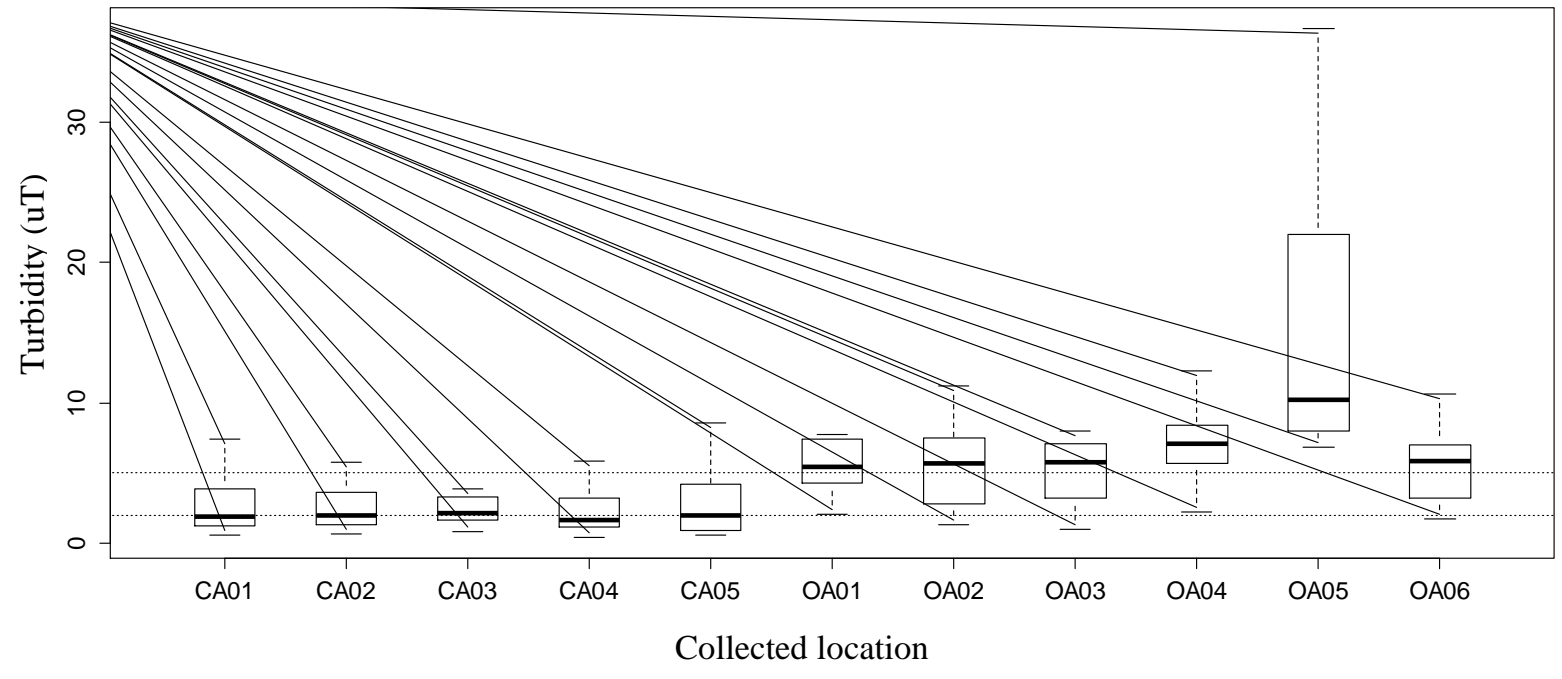

Source: Authors.

Regarding the temporal variation of $\mathrm{pH}$ in rainwater collected directly from the atmosphere in Congonhas and Ouro Branco (Figure 6) at all points, at least $75 \%$ of the samples showed values below 8 , which is the maximum limit recommended by NBR 15527 (ABNT, 2007). In some places, 100\% were below the maximum pH suggested in the norm. For the minimum pH limit, NBR 15527 (ABNT, 2007) recommends a value of 6. Figure 6 shows that only OA 03 and OA 06 do not have at least $75 \%$ of the samples collected in compliance with the standard. The median values in Congonhas ranged from 6.7 to 7.2 , while in Ouro Branco it was between 6.9 and 7.2.

Figure 6 - Temporal variation in the $\mathrm{pH}$ of rainwater collected directly from the atmosphere in Congonhas (CA) and Ouro Branco (OA).

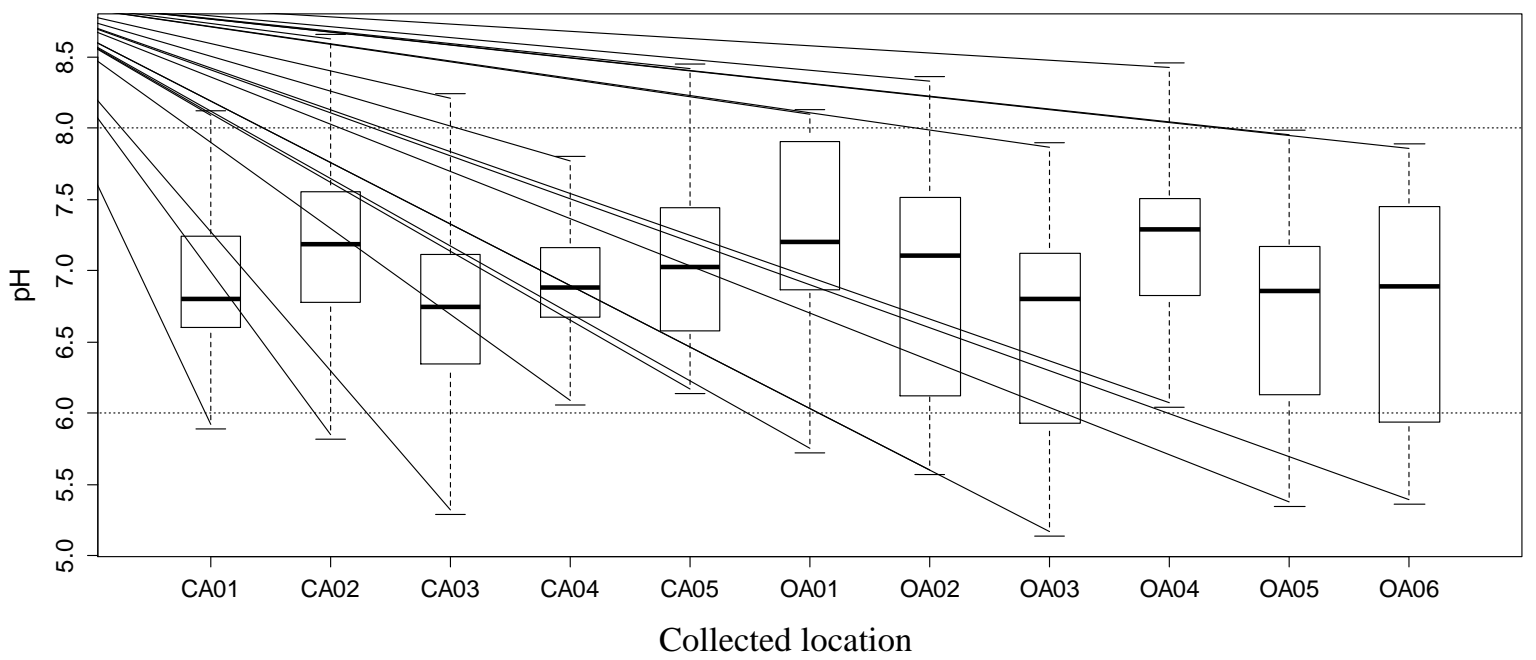

Source: Authors.

Comparing the locations analyzed in Congonhas, the point CA 03, which is located near the historic center where the Aleijadinho's sculptures are located, was the one with the lowest $\mathrm{pH}$ values. Cunha et al. (2009) considered that the $\mathrm{pH}$ of rainwater equal to or greater than 5.6 as normal, between 5 to 5.6 slightly acidic and less than 5 is acidic. Therefore, the only 
point that had slightly acid rain was CA 03, a fact that can cause some corrosive process in Aleijadinho's sculptures. Tiwari et al. (2012) also observed some mild acid rain events in China. These authors suggest that the reduction in $\mathrm{pH}$ values may be related to the high concentrations of ions resulting from vehicular emissions. As the point CA 03 is in the central area of the city, in addition to being a tourist spot, the high traffic of vehicles may be causing slightly acid rain.

Table 3 shows the results of the tests carried out to verify whether there was a spatial variation in the quality of rainwater collected directly from the atmosphere at points of Congonhas (CA) and Ouro Branco (OA). When the p-value found was greater than the level of significance of the test, all samples did not differ statistically from each other in relation to the analyzed parameter. Otherwise, the similarity between the samples was indicated by equal letters in the table line for a given parameter. The result presented in Table 3 was obtained by comparing all the combinations of the sampled locations, for the three parameters analyzed - apparent color, turbidity and $\mathrm{pH}$ - and for the cities of Congonhas and Ouro Branco.

Table 3 - Statistical comparison of averages of rainwater samples collected directly from the atmosphere in Congonhas (CA) and Ouro Branco $(\mathrm{OA})^{*}$.

\begin{tabular}{cccccccccccc}
\hline & CA & CA & CA & CA & CA & OA & OA & OA & OA & OA & OA \\
& 01 & 02 & $\mathbf{0 3}$ & $\mathbf{0 4}$ & $\mathbf{0 5}$ & $\mathbf{0 1}$ & $\mathbf{0 2}$ & $\mathbf{0 3}$ & $\mathbf{0 4}$ & $\mathbf{0 5}$ & $\mathbf{0 6}$ \\
\hline Apparent color & a & a & a & a & a & b & b & b & b & c & b \\
Turbidity & a & b & c & c & c & d & d & d & d & e & d \\
pH & a & b & c & d & e & fh & fh & g & h & fh & f \\
\hline
\end{tabular}

* Values followed by the same letters horizontally do not differ statistically. Source: Authors.

According to Table 3, it is clear that in Congonhas the apparent color was not affected by the spatial issue, since the sample means did not show any significant difference, even the five points, in which rainwater was collected directly from the atmosphere, presenting distinct local characteristics. The same did not happen in Ouro Branco, since the average of the apparent color of point OA 05 was different from the others. Righetto (2017) states that the accumulation of pollutants in a place comes from several sources, so that the individual effects are difficult to separate. Thus, it is impossible to explain the reason that made the apparent color averages statistically equal. However, this qualitative knowledge is important for planning measures that allow rainwater harvesting.

Regarding turbidity, the averages of the samples collected in CA 01 and CA 02 differed from each other and from the others, while CA 03 to CA 05 were statistically equal. Thus, it is observed that for this parameter there was spatial variation. In Ouro Branco, as observed in the apparent color, the turbidity of point OA 05 was the only one different from the others. This point is located close to a precast factory and on the side of a highway with a large volume of light and heavy vehicles passing through. Thus, these local characteristics may have significantly affected the quality of rainwater in terms of apparent color and turbidity.

For the last analyzed parameter - $\mathrm{pH}$ - the points $\mathrm{OA} 01, \mathrm{OA} 02$, OA 05 and OA 06 presented statistically equal means. The OA 04 point was equal to OA 01, OA 02 and OA 05, but differed from OA 06. The average pH of OA 03 differed from all others. In Congonhas, the averages were statistically different between all five points analyzed. Thus, it is observed that $\mathrm{pH}$ was the most sensitive parameter in terms of spatial variation. Fia et al. (2013) showed that the interaction of suspended ions, such as carbonate species, cations and inorganic anions, can promote $\mathrm{pH}$ variation. All of these ions can be in high concentrations in the atmosphere due to industrial and /or agricultural activities. As a result, local characteristics significantly influenced the $\mathrm{pH}$ values of samples collected in Congonhas and Ouro Branco. 
Table 3 show that none of the parameters observed in the points of Congonhas was statistically equal to the points of Ouro Branco. Thus, added to the spatial variation that can also be seen in Figures 4 to 6, differences in local characteristics that affect the quality of rainwater are evident between cities.

\subsection{Variation in the quality of rainwater after passing through the catchment surface}

In order to compare the influence on the catchment surface on the temporal variation in the quality of rainwater, Figures 7 to 9 show the dispersion of the apparent color, turbidity and $\mathrm{pH}$ results for samples collected directly from the atmosphere and those collected after passing through the roof.

Figure 7 - Comparison of the temporal variation of the apparent color of rainwater collected directly from the atmosphere and collected from the roofs (T), in Congonhas (CA and CT) and in Ouro Branco (OA and OT).

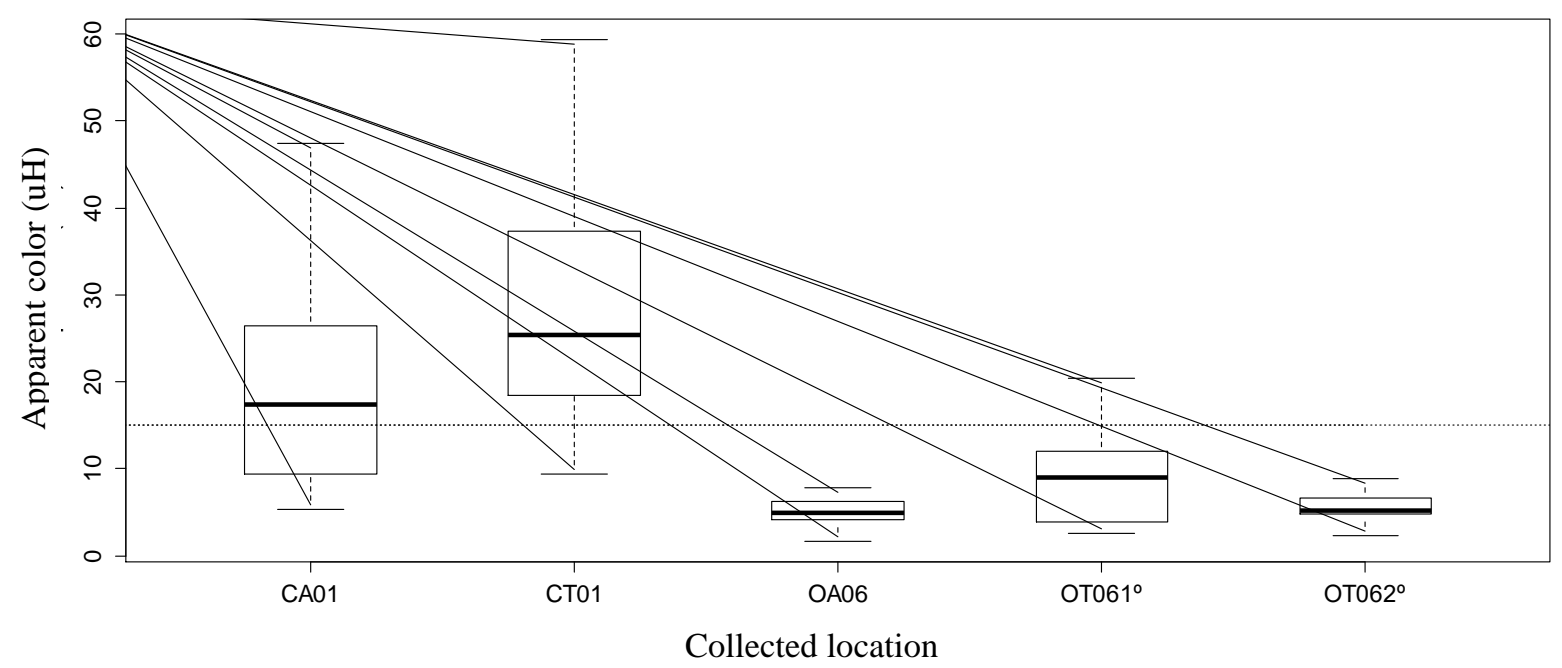

Source: Authors.

Figure 8 - Comparison of the temporal variation of rainwater turbidity collected directly from the atmosphere and collected from the roofs, in Congonhas (CA and CT) and Ouro Branco (OA and OT).

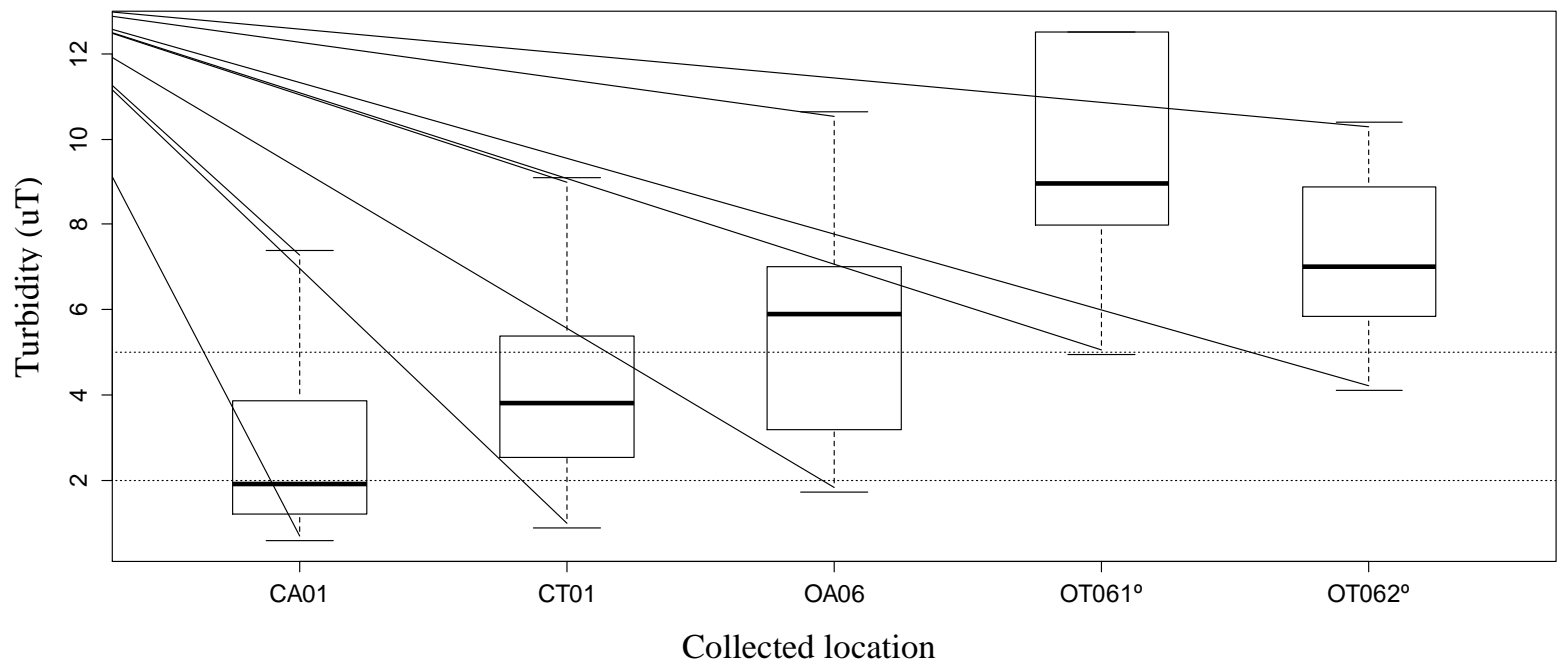

Source: Authors. 
Figure 9 - Comparison of the temporal variation of the $\mathrm{pH}$ of rainwater collected directly from the atmosphere and collected from the roofs (T), in Congonhas (CA and CT) and Ouro Branco (OA and OT).

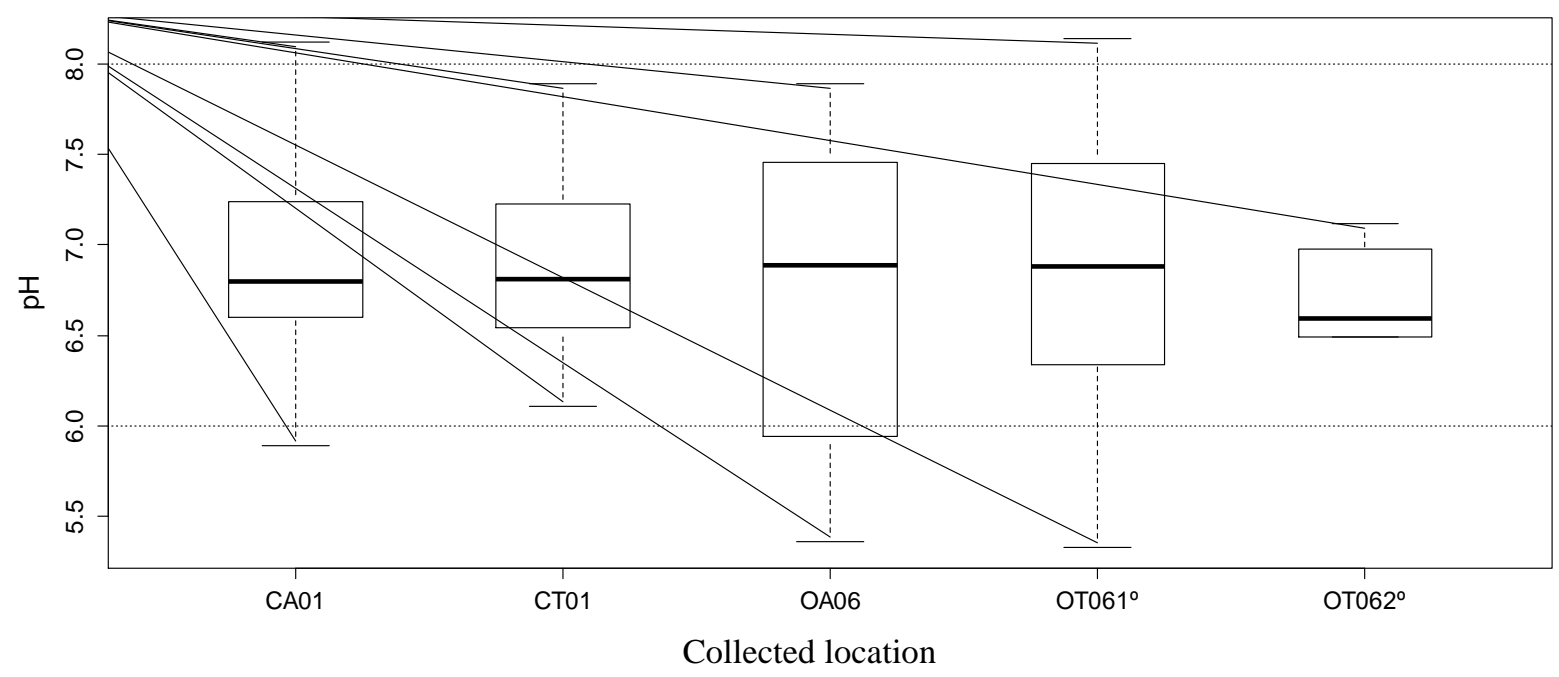

Source: Authors.

Analyzing Figures 7 and 8, it can be seen that the values of apparent color and turbidity of rainwater from roofs (CT 01 and OT $061^{\circ}$ ), referring to the volume of disposal, were higher than the values of samples collected directly from the atmosphere (CA 01 and OA 06). This observation corroborates with the one concluded by Andrade et al. (2017). However, it stands out that the worsening of the rainwater quality when having contact with the impurities of the roof tends not to change its classification based on the recommended by NBR 15527 (ABNT, 2007). As for the apparent color, the median value observed in CA 01 is higher than $15 \mathrm{uH}$, as well as the median value of CT 01 is also. The median value of OA 06 turbidity is greater than $5 \mathrm{uT}$, consequently, that of OT $061^{\circ}$ also does not meet the norm. On the other hand, both the median apparent color value of OA 06 and OT $061^{\circ}$ and the median turbidity value of CA 01 and CT 01 meet the norm.

In Figure 7 , for the OT $062^{\circ}$ point, it is observed that the dispersion of the apparent color was similar to the point OA 06 (point referring to the atmosphere water). In other words, the accumulation of impurities on the roof made the apparent color of the waste water higher (point OT $061^{\circ}$ ). As there was a gradual cleaning of the catchment area during the rain, the apparent color value of the roof water tended to be observed for water collected directly from the atmosphere. Thus, with regard to apparent color, the discharge volume recommended by NBR 15527 (ABNT, 2007) was sufficient to improve the quality of rainwater that came into contact with the catchment surface. However, this did not occur for turbidity (Figure 8), since the values of the samples referring to the point OA $062^{\circ}$ were lower than those of the samples of the disposal volume $\left(\mathrm{OA} 061^{\circ}\right.$ ), but not less than $5 \mathrm{uT}$, as recommended by the NBR 15527 (ABNT, 2007). In this case, the volume of rainwater discarded should be greater than $8.0 \mathrm{~L}$ to allow turbidity to meet the recommended. Thus, as also observed by Marangoni et al. (2019), the amount of rainwater to be discarded must be locally assessed, so that its quality is in accordance with NBR 15527 (ABNT, 2007).

The $\mathrm{pH}$ showed a different behavior from the other parameters, since the catchment surface did not influence its value (Figure 9). The median pH values for the points CA 01, CT 01, OA 06 and OT 061 ${ }^{\circ}$ were practically the same, all of which meet the recommended by NBR 15527 (ABNT, 2007). Hagemann and Gastaldini (2016) also observed that the pH values of rainwater samples collected from the roof were within the established by the norm.

According to the Figures 4 to 9, in some cases there were great variations in the quality of rainwater. For example, the apparent color at point CT 01 (Figure 7) ranged from approximately 9 to $59 \mathrm{uH}$; in OA 05 (Figure 5) the minimum turbidity was 8 and the maximum 38 uT, approximately; the CA 03 point (Figure 6) presented a pH in the range of 5.2 to 8.2. Thus, the 
rainwater treatment system must be adapted to these variations, mainly because the storage reservoirs are small, so that any change in the quality of the affluent water is quickly propagated to the stored water.

Table 4 shows the result of the comparison of the averages of the quality parameters of rainwater collected directly from the atmosphere and that collected after draining through the roof. In Congonhas, the three parameters of rainwater quality presented averages for samples collected directly from the atmosphere (CA 01) different from those collected from the roof (CT 01). In Ouro Branco, with respect to apparent color and turbidity, the samples of the first water on the roof (OT $\left.061^{\circ}\right)$ were different from the averages of the samples collected directly from the atmosphere (OA 06) and also different from the averages of the samples collected from the excess of the roof water discharge volume (OT $\left.062^{\circ}\right)$. However, the $\mathrm{pH}$ averages were statistically equal for the three points (OA 06 , OT $061^{\circ}$ and OT $062^{\circ}$ ). The averages of water in the atmosphere (OA 06), for all parameters, were the same as those of water coming from the roof and collected after the "first flush" (OT $\left.062^{\circ}\right)$. This shows that the first roof washing water (OT $061^{\circ}$ ) must be discarded in order to improve the quality of the water to be stored. Nevertheless, as previously discussed, remember that the volume of $8.0 \mathrm{~L}$ discarded improves the quality of rainwater, but it is not enough for this water to meet the recommended in NBR 15527 (ABNT, 2007).

Table 4 - Statistical comparison of averages of rainwater samples collected from the roof in Congonhas (CT) and Ouro Branco (OT) and samples collected directly from the atmosphere (CA e OA)*.

\begin{tabular}{cccccc}
\hline & CA 01 & CT 01 & OA 06 & OT 061 $^{\mathbf{0}}$ & OT 062 $^{\mathbf{2}}$ \\
\hline Apparent color & $\mathrm{a}$ & $\mathrm{b}$ & $\mathrm{c}$ & $\mathrm{d}$ & $\mathrm{c}$ \\
Turbidity & $\mathrm{a}$ & $\mathrm{b}$ & $\mathrm{c}$ & $\mathrm{d}$ & $\mathrm{c}$ \\
$\mathrm{pH}$ & $\mathrm{a}$ & $\mathrm{b}$ & $\mathrm{c}$ & $\mathrm{c}$ & $\mathrm{c}$ \\
\hline
\end{tabular}

* Values followed by the same letters horizontally do not differ statistically. Source: Authors.

When analyzing Table 4, it can be seen that the catchment surface tends to change the quality of rainwater at first. Subsequently, as this surface is being washed, the quality tends to be improved and to approach the quality of rainwater coming from the atmosphere. Marangoni et al. (2019) also concluded that the quality of rainwater varies over a rainy event.

\subsection{Modeling rainwater quality}

Using the SWMM model, the TSS concentrations that reach the drainage system in the contribution area in which the OT $061^{\circ}$ point is inserted are estimated, for a one-year return rain. The distribution of TSS concentrations and the hydrograph of the analyzed rain are shown in Figure 10. 
Figure 10 - Distribution of TSS concentrations that reach the drainage system and hydrograph of a rainy event.

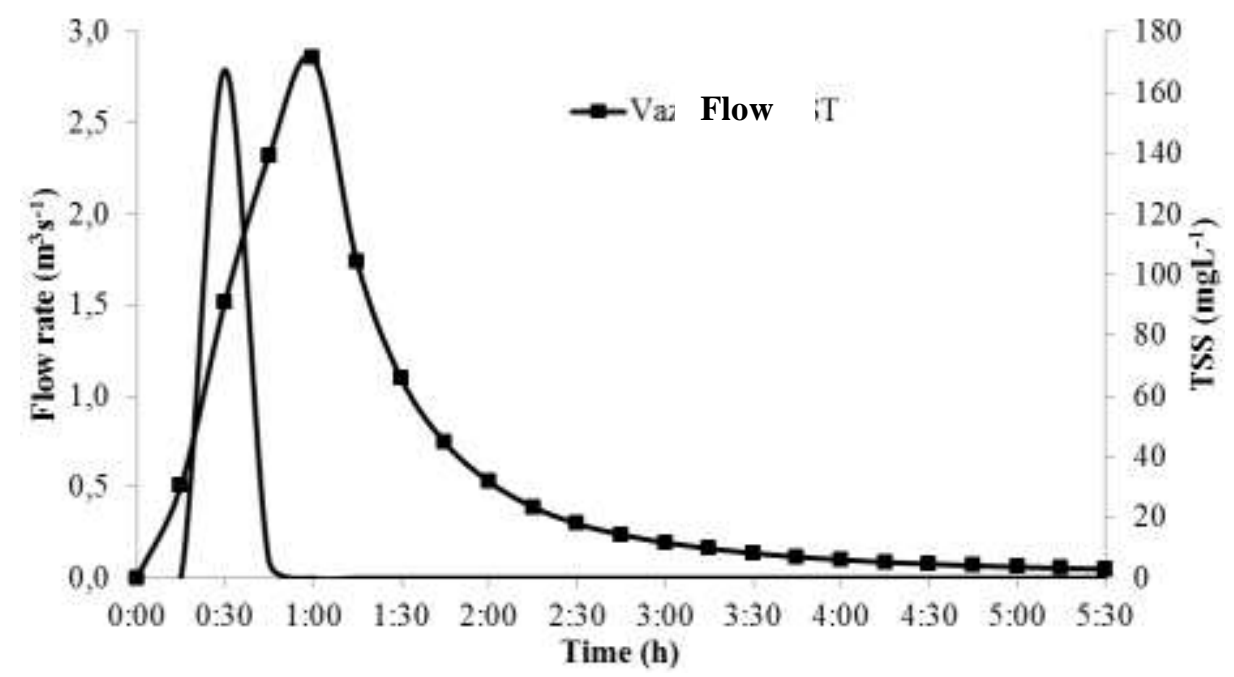

Source: Authors.

As seen in Figure 10, the rainy event produced a drain in the drainage system during 5:30 hours. During this period, the TSS concentration increased exponentially, reaching a peak of $167 \mathrm{mgL}^{-1}$. Tsuji et al (2019), assessing diffuse pollution in a small urban watershed in the Brazilian savannah, found concentrations that reached $201 \mathrm{mgL}^{-1}$, while Righetto et al. (2017) obtained values that varied between $772 \mathrm{mgL}^{-1}$ and $57.9 \mathrm{mgL}^{-1}$, in an urban basin with characteristics of land use and occupation similar to that of. In this way, it is clear that the rainwater present in the drainage system can reach high concentrations of TSS, as observed in this paper. Thus, the adopted methodology, which promoted the simulation of water quality based on the accumulation of solids that occurred on the roof and reached the drainage, allowed to represent the reality. This fact is a differential of this article, since the other papers cited performed the modeling based on TSS values measured in the drainage system and not on the roof.

Figure 10 shows that the TSS peak occurred 30 minutes after the beginning of the rain. This high growth in the initial phase is due to the first flush, and this behavior was also verified by Girão et al. (2017). Subsequently, there was a rapid decrease in the concentration of TSS, which is the result of the entrainment of solids by surface runoff and, consequently, washing of the drainage system, as also observed by Hur (2018), who proposed a different model from SWMM, using in this paper. Regarding the hydrograph, it is observed that the peak flow, approximately, $2.9 \mathrm{~m}^{3} \mathrm{~s}^{-1}$, occurred in one hour, that is, it did not coincide with the TSS peak. This confirms the need for the first rainwater to be discarded, as it has worse quality.

In Minas Gerais, the Deliberação Normativa Conjunta - Copam/CERH 01/2008 determines an TSS concentration of $100 \mathrm{mgL}^{-1}$, as a standard for the discharge of effluents into water bodies. Therefore, it is observed that the peak of $167 \mathrm{mgTSS}$ $\mathrm{L}^{-1}$ simulated for the drainage system and that is released in the receiving body is higher than acceptable. This shows that the capture of rainwater can reduce water pollution, since the total solids would be retained in the lot and would not reach the drainage system and, consequently, the watercourse.

\section{Conclusion}

In Congonhas and Ouro Branco there was a temporal variation in the quality of rainwater collected directly from the atmosphere in terms of the three parameters analyzed. Thus, the rainwater treatment system must be adapted to them, mainly because the storage reservoirs are small, so that any change in the quality of the affluent water is quickly propagated to the stored water. 
The quality of rainwater suffered spatial variation between the cities of Congonhas and Ouro Branco. In Ouro Branco, for example, there was significant variation in the quality of rainwater between locations that were only $0.3 \mathrm{~km}$ apart. Thus, it is evident that different local characteristics significantly affect the quality of rainwater.

The qualitative knowledge of the spatial-temporal variation presented in this paper is important for the planning of measures that allow the capture of rainwater. It should be noted that the same rainwater collection and treatment technique adopted for one location, may not be suitable for another.

Regarding the variation in the quality of rainwater after passing through the catchment surface, the rainwater referring to the volume of discharge showed values of apparent color and turbidity higher than those collected directly from the atmosphere. This occurred in both cities. Thus, it is clear that the volume of disposal must be studied locally, and, in some cases, it will have to be higher than that recommended by NBR 15527 (ABNT, 2007).

The TSS peak found was higher than that allowed by Copam/CERH 01/2008, which establishes the pattern of discharge of effluents into water bodies. Thus, it is clear that the capture of rainwater can reduce water pollution, since the total solids would be retained in the lot and would not reach the drainage system and, consequently, the watercourse.

In future works, the simulation of rainwater quality may be carried out based on parameters determined for Ouro Branco.

\section{Acknowledgments}

The authors thank the Federal University of São João del-Rei for the technical and financial support given to this work.

\section{References}

Associação Brasileira de Normas Técnicas. NBR 15.527:2007: Aproveitamento de água de chuva de coberturas de áreas urbanas para fins não potáveis. ABNT, 2007.

American Public Health Association (APHA); American Water Works Association (AWWA); Water Environmental Federation (WEF). (2012). Standard methods for the examination of water and wastewater. (22a ed.), Washington, D.C.

Amodio, M., Catino, S., Dambruoso, P. R., Gennaro, G., Di Gilio, A., Giungato, P., Laiola, E., Marzocca, A., Mazzone, A., Sardaro, A. \& Tutino, M. (2014). Atmospheric deposition: sampling procedures, analytical methods, and main recent findings from the scientific literature. Advances in Meteorology, 1-27. https://doi.org/10.1155/2014/161730.

Andrade, M. A. N., Lisboa, M. B. \& Lisboa, H. M. (2017). Reservatório de ardósia para sistemas de aproveitamento de água de chuva. Revista Brasileira de Engenharia Sanitária e Ambiental, 22(3), 563-570. https://doi.org/10.1590/S1413-41522017177829.

Angala, H. A. N., Tandlich, R., Ngqwala, N. P. \& Zuma, B. M. (2019). Efficiency of a decentralised system in the treatment of rainwater in South Africa. Air and Water-Components of the Environment, 1-8. https://doi.org/10.24193/AWC2019_01.

Bashara, M. Z. I., Karimb, M. R. \& Imteazc, M. A. (2018). Reliability and economic analysis of urban rainwater harvesting: A comparative study within six major cities of Bangladesh. Resources, Conservation \& Recycling, 133, 146-154. https://doi.org/10.1016/j.resconrec.2018.01.025.

Behmel, S., Damour, M. \& Ludwig, R. (2016). Water quality monitoring strategies - a review and future perspectives. Science of the Total Environment, 571, 1312-1329. https://doi.org/10.1016/j.scitotenv.2016.06.235.

Brandão, J. L. B. \& Marcon, P. (2018a). SIMCAP: ferramenta computacional para auxiliar a tomada de decisão sobre a implantação de sistemas de captação de águas pluviais. Revista Brasileira de Engenharia Sanitária e Ambiental, 23(6), 1027-1030. https://doi.org/10.1590/S1413-41522018129229.

Brandão, J. L. B. \& Marcon, P. (2018b). Análise dos métodos de dimensionamento de reservatórios de águas pluviais sugeridos pela NBR 15527/07 com base na simulação diária. Revista Brasileira de Engenharia Sanitária e Ambiental, 23(6), 1031-1041. https://doi.org/10.1590/S1413-41522018129228.

Campisano, A., Butler, D., Ward, S., Burns, M. J., Friedler, E., Debusk, K., FisherJeffes, L. N., Ghisi, E., Rahman, A., Furumai, H. \& Han, M. (2017). Urban rainwater harvesting systems: Research, implementation and future perspectives. Water Research, 115, 195-209. https://doi.org/10.1016/j.watres.2017.02.056.

Chaib, E. B., Rodrigues, F. C., Brenner, H., Maia, B. H. \& Nascimento, N. O. (2015). Avaliação do potencial de redução do consumo de água potável por meio da implantação de sistemas de aproveitamento de água de chuva em edificações unifamiliares. Revista Brasileira de Recursos Hídricos, 20 (3), 605-614. https://doi.org/10.21168/rbrh.v20n3. 
Chen, L., Dai, Y., Zhi, X., Xie, H. \& Shen, Z. (2018). Quantifying nonpoint source emissions and their water quality responses in a complex catchment: A case study of a typical urban-rural mixed catchment. Journal of Hydrology, 559, 110-121. https://doi.org/10.1016/j.jhydrol.2018.02.034.

Cunha, G. R., Santi, A., Dalmago, G. A., Pires, J. L. F. \& Pasinato, A. (2009). Dinâmica do pH da água das chuvas em Passo Fundo, RS. Pesquisa Agropecuária Brasileira, 44(4), 339-346. http://dx.doi.org/10.1590/S0100-204X2009000400002.

Gaitán, M. C. P. \& Teixeira, B. A. N. (2020). Aproveitamento de água pluvial e sua relação com ações de conservação de água: estudo de caso em hospital universitário, São Carlos (SP). Revista Brasileira de Engenharia Sanitária e Ambiental, 25(1), 133-144. https://doi.org/10.1590/s1413-41522020189032.

Fia, R., Frizzarim, S. S. \& Fia, F. R. L. (2013). Análise Qualitativa de Poluentes na Água das Chuvas em Lavras - MG. Revista Brasileira de Recursos Hídricos, 18(3), 269-278. https://doi.org/10.21168/rbrh.v18n2.

Girão, L. F. O., Simões, N. E. C., Marques, J. A. A. S., Leitão, J. P. C. \& Pina, R. D. (2017). Modelação hidráulica e de qualidade da água dos sistemas de drenagem em meios urbanos. Revista Brasileira de Engenharia Sanitária e Ambiental, 22(2), 351-360. https://doi.org/10.1590/S1413-41522016161318.

Gomes, U. A. F., Domenech, L., Pena, J. L., Heller, L., Palmier, L. R (2014). A captação de água de chuva no Brasil: novos aportes a partir de um olhar internacional. RBRH: Revista Brasileira de Recursos Hídricos, 19(1), 7-16. https://doi.org/10.21168/rbrh.v19n1.

Hagemann, S. E. \& Gastaldini, M. C. C. (2016). Variação da qualidade da água de chuva com a precipitação: aplicação à cidade de Santa Maria - RS. Revista Brasileira de Recursos Hídricos, 21(3), 525-536. http://dx.doi.org/10.1590/2318-0331.011615010.

Hur, S., Nam, K., Kim, J. \& Kwak. C (2018). Development of urban runoff model FFC-QUAL for first-flush water-quality analysis in urban drainage basins. Journal of Environmental Management, 205, 73-84. https://doi.org/10.1016/j.jenvman.2017.09.060.

Instituto de Pesquisas Tecnológicas (IPT). (2015). Manual para captação emergencial e uso doméstico de água de chuva.

Lopes, E. L., Mendes, H. M., Mendes, R. L. R. \& Ramos, F. C. D. (2019). Potencial de captação de água de chuva em unidades familiares rurais do município de Breves-PA. Cadernos de Arquitetura e Urbanismo, 24(3), 1-11. http://dx.doi.org/10.18830/issn.1679-0944.n23.2019.06.

Marangoni, T. T., Oliveira, J. N. \& Libânio, M. (2019). Avaliação quantitativa e qualitativa do emprego de paredes como nova perspectiva para captação de água de chuva. Revista Brasileira de Engenharia Sanitária e Ambiental, 21(1), 575-584. http://dx.doi.org/10.1590/S1413-41522019183007.

Mimura, A. M. S., Almeida, J. M., Vaz, F. A. S., Oliveira, M. A. L, Ferreira, C. C. M. \& Silva, J. C. J. (2016). Chemical composition monitoring of tropical rainwater during an atypical dry year. Atmospheric Research, 169, 391-399. http://dx.doi.org/10.1016/j.atmosres.2015.11.001.

MINAS GERAIS. Conselho Estadual de Política Ambiental (Copam). Conselho Estadual de Recursos Hídricos do Estado de Minas Gerais (CERH). Deliberação Normativa Conjunta COPAM/CERH n ${ }^{\circ} 01$, de 05 de Maio de 2008. Dispõe sobre a classificação dos corpos hídricos e diretrizes ambientais para o seu enquadramento, bem como, estabelece as condições e padrões de lançamento de efluentes, e dá outras providências. MG. 2008.

Moruzzi, R. B., Sousa Júnior, W. C., Arduino, J. \& Julio, M. (2016). Avaliação do aproveitamento de água pluvial para atendimento de uso não potável no Aeroporto Internacional de São Paulo/Guarulhos. Revista Brasileira de Engenharia Sanitária e Ambiental, 21(1), 17-28. https://doi.org/10.1590/S141341520201600100117248 .

Moruzzi, R. B. \& Leão, C. L. P. (2019). Estimativa da correção do coeficiente de retorno de esgoto sanitário em habitações com sistemas de aproveitamento de água pluvial: estudo de caso da cidade de Bauru, SP. Revista Brasileira de Engenharia Sanitária e Ambiental, 24(1), 45-53. https://doi.org/10.1590/S141341522019151601 .

Nakada, L. Y. K. \& Moruzzi, R. B. (2014). Variabilidade qualitativa de águas pluviais coletadas em telhado e sua importância na concepção do sistema de tratamento. Revista Brasileira de Engenharia Sanitária e Ambiental, 19(1), 1-9. http://dx.doi.org/10.1590/S1413-41522014000100001.

PROSAB. (2009). Manejo de Águas Pluviais Urbanas. ABES.

Righetto, A. M., Gomes, K. M. \& Freitas, F. R. S. (2017). Poluição difusa nas águas pluviais de uma bacia de drenagem urbana. Revista Brasileira de Engenharia Sanitária e Ambiental, 22(6), 1109-1120. https://doi.org/10.1590/S1413-41522017162357.

Rosa, D. J., Clausen, J. C. \& Dietz, M. E. (2015). Calibration and verification of SWMM for low impact development. Journal of the American Water Resources Association, 51(3), 746-757. https://doi.org/10.1111/jawr.12272.

Sánchez, A. S., Cohim, E. \& Kalid, R. A. (2015). A review on physicochemical and microbiological contamination of roof-harvested rainwater in urban areas. Sustainability of Water Quality and Ecology, 6, 119-137. http://dx.doi.org/10.1016/j.swaqe.2015.04.002.

Santos, S. M. \& Farias, M. M. M. W. E. C. (2017). Potential for rainwater harvesting in a dry climate: Assessments in a semiarid region in northeast Brazil. Journal of Cleaner Production, 164, 1007-1015. https://dx.doi.org/10.1016/j.jclepro.2017.06.251.

Sazakli, E., Alexopoulos, A. \& Leotsinidis, M. (2007). Rainwater harvesting, quality assessment and utilization in Kefalonia Island, Greece. Water Research, 41, 2030-2047. https://dx.doi.org/10.1016/j.watres.2007.01.037.

Souza, M. C., Santos, D. B., Rios, M. L., Silva Neto, M. D., Azevedo, D. O. \& Batista, R. O. (2012). Quality indicators and potential of rain water harvesting on paved roads in semiarid Bahia. Water Resources and Irrigation Management, 1(1), 71-80.

Stahn, H. \& Tomini, A. (2017). On conjunctive management of groundwater and rainwater. Resource and Energy Economics, 49, 186-200. https://doi.org/10.1016/j.reseneeco.2017.05.002.

Stewart, C., Kim, N. D., Johnston, D. M. \& Nayyerloo, M. (2016). Health hazards associated with consumption of roof-collected rainwater in urban areas in emergency situations. International Journal of Environmental Research and Public Health, 13(10), 1012-1039. https://dx.doi.org/10.3390\%2Fijerph13101012. 
Research, Society and Development, v. 10, n. 3, e45810313598, 2021

(CC BY 4.0) | ISSN 2525-3409 | DOI: http://dx.doi.org/10.33448/rsd-v10i3.13598

Strauss, A., Reyneke, B., Waso, M., \& Khan, W (2018). Compound parabolic collector solar disinfection system for the treatment of harvested rainwater. Environmental Science: Water Research \& Technology, 4, 976-991. https://doi.org/10.1039/c8ew00152a.

Tarqui, J. L. Z., Carvalho, M. F., Santos, C. M. L. \& Santos, J. E. (2019). Avaliação do escoamento superficial de águas pluviais em pavimento de blocos de solo-cimento. Revista Brasileira de Engenharia Sanitária e Ambiental, 24(2), 403-410. https://doi.org/10.1590/S1413-41522019153148.

Thériault, A. \& Duchesne, S. (2012) Urban water quality modelling: quantifying the fecal coliform load in the Beauport River. In 9th International Conference on Urban Drainage Modelling, Belgrade.

Tiwari, S., Chate, D. M., Bisht, D. S., Srivastava, M. K. \& Padmanabhamurty, B. (2012). Rainwater chemistry in the North Western Himalayan Region, India. Atmospheric Research, 105, 128-138. https://doi.org/10.1016/j.atmosres.2011.09.006.

Tsuji, T. M. (2018). Monitoring and modeling of rainwater drainage in the urban core of the Riacho Fundo stream basin, Brasília - DF (Masters dissertation). Department of Civil and Environmental Engineering, University Brasília, Brasília.

Tsuji, T. M., Costa, M. E. L. \& Koide, S. (2019). Diffuse pollution monitoring and modelling of small urban watershed in Brazil Cerrado. Water Science \& Technology, 79(10), 2-10. https://doi.org/10.2166/wst.2019.190.

Waso, M., Khan, S., Singh, A., McMichael, S., Ahmed, W., Fernández-Ibáñez, P. Byrne, J. A., \& Khan, W. (2020). Predatory bacteria in combination with solar disinfection and solar photocatalysis for the treatment of rainwater. Water Research, 169, 1-10. https://doi.org/10.1016/j.watres.2019.115281. 